\title{
Illicit Cultural Property from Latin America: \\ Looting, Trafficking, and Sale
}

\section{Donna Yates}

This chapter will provide a broad overview of the theft, smuggling, and illegal sale of cultural objects from Latin America. First, I will describe the two categories of Latin American cultural property covered by this chapter (pre-Conquest artefacts, colonial sacred art), and then consider the form and functioning of the illicit trade in Latin American antiquities. I will discuss the on-the-ground devastation of the historic trade in looted Latin American objects and present a model of a historic antiquities trafficking network. This will be illustrated by two case studies: the theft and trafficking of a large Maya sculpture from the site of Machaquilá, Guatemala, and of the Church of Challapampa, Peru. The paper will close with a brief recommendation and an outline of the various outside forces that appear to play a significant role in the continued looting and trafficking of Latin American cultural objects. Among these important forces to consider are deforestation, human migration, the narcotics trade, local and regional instability, community insecurity, poverty, globalization, and developmental disparities. If reducing the illicit trade in Latin American cultural property is our goal, then all current and future policy must address these issues.

\section{Latin American cultural property}

\section{Ancient items from North and South America}

Before the Spanish Conquest, every modern Latin American State (in this discussion, including Brazil and Belize) housed complex cultures which produced cultural property that has since been looted, trafficked, and sold on the international market. However, the primary focus of the illicit trade in Latin American archaeological objects has historically been the formidable civilizations of the central and northern Andes, Mesoamerica, and the 'connecting' cultures of Costa Rica and Panama. The achievements of these cultures translate into beautiful cultural objects which have become desirable on the antiquities market, especially in the last 60 years. The rise in popularity of these items is tied to a growing Western collecting interest in so-called 'primitive' and 'tribal' art - racist art market terms that are artificially applied to non-Western and non-Eastern cultural objects. This obsession with the 'primitive' started in the 1950s, became popular in the 1960s, and was firmly established in the international art market in the 1970s. By the 1980s most major (and many minor) auction houses offered 'tribal' art sales and several offered sales of specifically 'precolumbian' art (Gilgan 2001; Yates 2006). The term 'precolumbian' is not without its own serious issues, but will be regretfully used here as it is used by the art market. Based on market analysis, certain classes of Latin American artefacts have historically been in demand on the market and likely still are. This is a very rough characterization of a complex market and further details can be found in a number of studies (e.g. Alva 2001; Coe 1993; Coggins 1969, 1976; Gilgan 2001; Gutchen 1983; Hernández Sánchez 2008; Levine and Luna 2013; Luke and Henderson 2006; Parades Maury 1996; Pendergast 1991; Pendergast and Graham 1981; Robertson 1972; Sheets 1973; Yates 2006, 2011, 2014a, 2014b). Thus, the market in Latin American antiquities mostly consists of the following: 
- Ceramics. Ceramics from throughout Latin America appear for sale on the international market. Of particular focus, and thus at particular cost, are the beautiful Maya polychrome vessel of the Meosamerican lowlands, especially vessels with figural scenes and/or Maya writing, and Moche moulded spouted vessels from Peru made in the form of three dimensional animals, objects, and human portraits.

- Metalwork. The cultures that inhabited the area from Peru through Panama were masterful metalworkers who produced cultural objects made of gold, silver, and copper. The majority of these metal objects were used for ceremonial adornment both in life and in death. They are rarely seen as true armour or weaponry, as the material is too soft to be effective. The spectacular funerary masks of the Moche and Chimú of Peru, the jewellery of Ecuador and Colombia, and the mythical animals and other composite beasts of the Darien of Panama, all wrought in gold, are among the most sought-after pieces on the market. Gold, most certainly, is the market's focus, although silver is also of interest, e.g. Inka silver drinking vessels and llama statuettes. Copper artefacts are rarer on the international market as survive poorly.

- Textile. Because of the arid conditions of the coastal areas of Peru and northern Chile and because a number of ancient cultures of the region specifically deposited their dead in locations that favoured natural mummification, many examples of ancient textile craft survive from that area. The Paracas, Nasca, and Wari cultures, among others, wrapped their important dead in up to 100 pieces of textile before placing them in desert burials. These textiles are some of the most intricate and advanced seen in the ancient world, displaying mythological scenes in bright colours using embroidery, tapestry weaving, and printing. Featherwork also survives. These pieces, although fragile, have been extremely popular on the market as they are considered to be the finest in the world.

- Stonework. Latin American stone sculpture is both rare on the market and highly sought. Historically the most prized and most looted type of stone sculpture from the region have been the stelae, altars, and other architectural pieces produced by the Maya. Many of these sculptures are massive. Smaller pieces, such as zoomorphic grinding stones from Costa Rica, are also seen, as are various kinds of statuary from Central Mexico. There is a particular price premium on Aztec, Toltec, sculptures (among others) that depict such things as skulls and sacrifice.

- Figurines. Both ceramic and stone figurines are commonly seen on the market. A particularly popular category of these in the past have been the various styles of human and animal figurines from western Mexican shaft tombs, particularly those that depict dogs. Olmec figurines of any type are prized, perhaps because of the popular mystique associated with that culture. Maya figurines thought to be from the island of Jaina are sought for their intricate, lifelike scenes. In Ecuador, the schematic figurines of the Valdivia culture have been a particular focus of collecting. Figurines are some of the most common but most varied Latin American object type on the market. 
It should be noted that since the very earliest days of the Latin American antiquities market massive numbers of fakes have polluted the corpus. While there are a number of techniques that can be used to determine if an object is fake, none are fool-proof and examples exist of fakers fooling every technique and every expert. Even those items that are difficult to fake can be used to produce fakes, e.g. portions of ancient textiles have been refashioned in to marketable 'ancient' dolls. Estimates of how many and speculations about which objects are fake fill the literature and some experts have gone as far as to declare that most Latin American antiquities on the market in a number of the previously mentioned categories are fake (e.g. Bruhns and Kelker).

\section{Colonial and republican sacred art from Churches}

Although little discussed in the academic literature and rarely a focus of international discussion, there exists a strong demand for colonial and republican period art, primarily from Latin American churches. In some locations, the incidents of cultural property theft from churches have far exceeded incidents of theft from archaeological contexts. Evangilisation was a core concern of the Spanish Conquest and it was a conquering technique: pre-Conquest temples were razed and churches were built in their stead often out of the same stone, to harness the power of the already holy place. As indigenous populations were reduced into villages, each village was given a church. Over the years, these churches would filled with both local and international religious art, often in a unique local style. There has been a market demand for these objects for decades, however early work on this subject indicates that there was an uptick in demand starting in the 1990 s and continuing into the 2000s, which perhaps coincides with popular interior decorating trends that favour many of these objects. There are a number of terms that are used to describe these pieces and, for the sake of clarity, I will use the term 'sacred art'. The following categories of object have historically been on demand in the market and likely still are:

- Silverwork. For much of the Colonial period, Latin America produced the majority of the world's silver, both from Central Mexico and, more significantly, from the silver mountain of Potosí, Bolivia. The result is that a significant number of Indigenous craftspeople had experience with the metal and the metal was locally available. Thus in the Andes, and to a lesser extent the rest of Latin America, even the smallest churches in the poorest communities contain sacred silver items. In demand on the market are silver monstrances, candle sticks, altar pieces (even very large ones), and other ritual items from all colonial periods. Also of market interests are the jewellery, crowns, resplendors, spurs, and other adornments of figures of the holy family and saints. If it is colonial and silver, there will be a market for it.

- Icons/Figures/Sculptures. These pieces are sold under a number of names, but they are sculptures of the Virgin, of Christ, and of the Saints, wrought in a number of different materials with a core of polychromed wood, which would be the object of directed worship within a church. Particularly fine, and thus particularly desirable figures have inlaid eyes, elaborate dress, or previously mentioned silver or gold accessories. 
- Paintings. Both European and indigenous paintings adorn the churches of Latin America, with many of the indigenous ones displaying techniques assigned to various local 'schools'. It is this sense of the foreign and the parochial, the idea of arts at the periphery of the European model, that drive the demand for colonial paintings in general and colonial church paintings specifically. Some of the most sought are those that represent indigenous themes within Christian contexts, e.g. dark Virgins as mountains, angels with large guns, etc. The historic frames that contain these paintings are also sought on the market.

- Bells. Church bell theft is a major issue in Latin America but, as it stands, there is no evidence that these bells are sold intact on the international market. Although there is some market for historic church bells, it is thought these are likely melted down and sold as scrap.

- Furniture. Perhaps the most difficult type of sacred art to track because of misunderstandings as to whether furniture should be documented as heritage (by the law of most Latin American countries, it should), very old furniture which can often be found in churches is sought on what is usually considered to be the antiques market. A number of recorded church thefts include the theft of historic furniture. The sources of these antiques are rarely questioned on the market and this could be a much bigger issue than we know.

Unlike archaeological pieces, which can only come from archaeological sites, sacred art is not only found in churches. Because of the continued importance of Catholicism to Latin American culture and identity, many (but not all) of the categories of objects listed above could be found in a private residence and thus be passed down through families. This, perhaps, allows a buyer to imagine that the items they purchase are legitimate, even if they are not. That said, in most Latin American jurisdictions, items of a certain age, even if they are privately held must be registered with the government and cannot be exported from the country without a permit that is unlikely to be granted. For this reason, all Latin American sacred art on the international market should be treated as suspect until it is proven otherwise.

\section{The Latin American antiquities trade pre-1970}

It is difficult to put an exact date on the start of looting in Latin America and various activities of the late 1800 s could be considered looting. However, after the early 1900s, true scientific archaeology was conducted in Central and South America by both foreign and local scholars and after about 1925, particularly in Peru, scholars reporting that sites were being looted and objects were coming up for sale on the market in their country of origin (Tello 1959). Some of this early looting was devastating, for example the looting of the Paracas Necropolis for textiles from 1931 to 1933, but truly endemic looting came later. At this time the market for these objects was local or international in a local way: the objects were purchased in-country by foreign diplomats and business people. The issues were serious enough to incite a number of countries in the region to pass very early laws claiming ownership of all archaeological objects and prohibiting all digging and exporting of artefacts without a government permit, e.g. El Salvador in 1903 
(Decree no. 4347), Bolivia in 1906 (Law of 3 October 1906), Peru in 1929 (Law no. 6634), Guatemala in 1947 (Decrete no. 425 of 1947).

The scale of artefact looting and trafficking greatly increased when the market for Latin American antiquities became truly international. As points of sale to collectors shifted from the streets of Lima or Mexico City to New York, Paris, or Hollywood, and as demand increased, trafficking networks (both simple and complex) grew to fill the important middle transit stage of the antiquities smuggling chain and the pillage of archaeological sites rose sharply. Because most Latin American counties outlawed the export of antiquities before an international market grew for them, all the Latin American antiquities on the market were tainted by crime and were illegal in some jurisdictions. This is still the case.

That said, there was no desire on the part of dealers and buyers (including major museums) to respect the law of the countries of origin at that time. It is often said that Latin American source countries have been treated with disrespect and indignity by the international antiquities trade. At this time pre-Conquest objects were the primary focus of looting and trafficking. Churches were robbed and early collections of colonial sacred art began to grow but the scale was not at the level seen today. Furthermore, many of the countries in question had not fully clarified their ownership of, and export bans on, sacred art at this time. Of course, sacred art that was outright stolen from a church was still stolen property, but at least from recorded sources, sacred art trafficking would largely come later.

Although there are a number of ways Latin American antiquities left their country of origin at this time, a simplified model might include the following elements: a notable site would be located by locals, either people living in a nearby village or those who move through the jungle or desert as part of their subsistence activities. Because they know that there is a market for ancient items, locals would either sell this information to a local looting group or notify an intermediary who would finance illicit digging. Locals with previous experience might loot the site themselves. The items would quickly pass out of the hands of the locals and into those of an in-country intermediary, often but not always an expatriate, who worked with a particular out-of-country intermediary to smuggle the antiquities. The in-country intermediary would arrange the transit stage of the antiquities, perhaps with the help of local corruption, perhaps because of their own access to shipping methods. These intermediaries would either be paid upfront or given a cut of the future sale. The out-of-country intermediary would then receive the antiquities in the country of sale and 'clean' them both figuratively and literally for sale on the 'legitimate market', serving as a Janus figure connecting the criminal underworld and the respectable market (Mackenzie and Davis 2014).

These intermediaries might be dealers themselves who would then sell the object on to a museum or collector, particularly a collector that they had a working relationship sourcing particular objects for. They also might be dealers to dealers, supplying objects to the established store-front and catalogue style dealerships. Oftentimes, it was these out-of-country intermediaries would supply a plausible back story and false paperwork to legitimize the smuggled objects. Finally, the object would be sold to a 'legitimate' collector or museum who was fully aware of the illicit nature of the market they engaged in but would specifically choose to neither ask too many questions nor notify the authorities of suspect behaviour. There was almost no risk of punishment for any individual beyond the stage of in-country intermediary. 
The following case study illustrates an extreme version of this model which, due to its relatively late date, was fully exposed. This represents a rare example of traffickers being caught and brought to justice and there is every reason to think that previous networked trafficking incidents from Latin America were much like this one, only with a lot less hesitation on the part of buyers.

\section{Network case study: Machaquilá Stela 2 (Guatemala)}

Machaquilá is a Maya site located in an isolated part of Guatemala’s Petén department (La Porte et al. 2009). It is a difficult site to access due to rough terrain and a lack of natural resources (Just 2007: 3). Its remote location appears to have buffered it from the fallout of the endemic conflict of the Classic period, and it experienced a brief florescence during the $9^{\text {th }}$ century AD in the wake of the Tikal-Calakmul War (Just 2007: 3). Afterwards it fell into decline along with the rest of the Petén, although the people of Machaquilá produced stela for nearly 40 years after other sites were abandoned (Just 2007: 3).

Numerous sculpted stones were found by archaeologists at Machaquilá, e.g. Ian Graham found 17 stelae and six altars in the 1960s, but as of the time of writing there are no carved monuments at the site (La Porte et al. 2009). Many were looted during the endemic pillage of the Petén in the 1960s and 1970s and the rest were removed for their own protection by the Guatemalan government.

Two Costa Rican brothers working for the Union Oil Company discovered Machaquilá some time before 1961. Archaeologist Ian Graham contacted the men and they confirmed their discovery by showing him a carved stone they had brought from the site that was being using as a doorstop (Graham 2010: 250). In May 1961, Graham visited Machaquilá, which he named after the local river, and recorded the presence of stelae. In 1962, he spent considerably more time at the site specifically to record the various carved stelae via photographs, drawings, and latex moulds (Graham 2010: 254). Thus, Machaquilá Stela 2 was discovered by Graham, who drew and photographed the sculpture in situ, establishing that it was, indeed, in Guatemala after Guatemala had declared ownership of all archaeological objects within its territory. Unless otherwise stated, the following account of the trafficking of Machaquilá Stela 2 is derived from the memoirs of Ian Graham (2010: 436-438).

In 1971, Dr William Bullard of the University of Florida contacted Ian Graham to inform him that Machaquilá Stela 2 had been looted, trafficked, and exhibited for sale in Florida. The stela had been bought from looters (who cut it to pieces) by Jorge Alamilla, a Belizean who was known to be involved in the antiquities trade for around $\$ 3,000$. It was passed on to three men: Ed Dwyer, according to Graham, the brother-in-law of the owner of a lumber company that operated in the Petén; Johnnie Brown Fell; and his cousin Harry Brown, who were both in the shrimp-exporting business. The stela was stored in Fell's fish-packing plant in Belize City for a period of time (Hughes 1977: 149). The men moved the stela, which was in fragments, to Miami, Florida in a boat concealed by a shipment of shrimp. The fragments of the stela had been packed into boxes labeled 'personal effects' and marked with the address of restorer Clive Hollinshead in Santa Fe Springs, California (Hughes 1977: 149). Once in Florida, Hollinshead was brought in to restore the piece.

After the restoration, Fell and Dwyer bought a station wagon (Graham recounts that it was Fell and Alamilla, but the court record reports it was Dwyer), put the stela in it, and drove to New York City. They offered the stela to the Brooklyn Museum, to dealer André Emmerich, and then to dealer Leonardo Patterson. All three declined to buy it, but 
Patterson suggested they offer the sculpture to Marjorie Neikrug who owned a gallery in the city. While Fell and Dwyer were discussing the piece with her, the car containing the stela was towed away for illegal parking but they managed to retrieve it. When Neikrug turned down the stela, the two men drove to Milwaukee, Wisconsin, where they offered it to Glenn Rittenour, a Methodist minister who later testified against them at trial. $\mathrm{He}$, too, turned the stela down. Federal records indicate the men also stopped in Decatur, Georgia, and in North Carolina in attempts to sell the piece. Fell and Dwyer continued their drive, eventually bringing the stela to Los Angeles were they sold it to the restorer Clive Hollinshead. The asking price for the stela during this journey is said to have been $\$ 300,000$ (Meyer 1973: 33).

After uncovering this story via a series of well-placed telephone calls, Graham contacted the FBI who informed him that the stela could be recovered via the National Stolen Property Act's ban on the interstate transportation of stolen objects (18 U.S.C. 2314). He was told that at trial, it must be shown that the men in possession of the stela knew it was stolen and had transported the object from one State to another with full knowledge of that status. To secure this information, Graham asked a friend of his to pose as a potential buyer interested in Maya stelae. Hollinshead showed her Machaquilá Stela 2, which was in his garage at the time, proving that it had been transported, which provided enough evidence for the FBI to intervene.

On 28 August 1972, a federal Grand Jury indicted Clive Hollinshead, Jorge Alamilla, and Johnnie Fell on charges of conspiracy to transport stolen goods in interstate and foreign commerce and causing the transportation of stolen property in interstate commerce (Hughes 1977: 1949). According to the indictment, Hollinshead had a prior arrangement with Alamilla for the procurement of looted and smuggled Maya objects. The indictment stated that Hollinshead was on-hand in Belize during the smuggling process, as were unnamed Guatemalan officials who were bribed (Hughes 1977: 149). In February 1973, Hollinshead et al. was tried in a Los Angeles Federal District Court. Graham, who was serving as a witness, was unable to watch the most of the trial. However, he recounts that Ed Dwyer, who was one of the original purchasers of the stela while it was still in Central America, turned State's evidence and was spared any legal repercussions. Jorge Alamilla, who was not a US citizen, did not appear, presumably fleeing to his native Belize.

The Court found that Ted Wiener, a man based in Dallas and involved in the oil business, had financed Hollinshead's purchase of the stela in return for a cut of any profit from resale. Hollinshead's seized records showed that another stela from Machaquilá was, at that time, in the possession of Harry Brown in Helena, Arkansas, but that stela had been mostly destroyed in the looting process having been broken into 25 pieces. It was impounded by the FBI in January of 1972 and was later identified as Machaquilá Stela 5 (Meyer 1973: 33). Allegedly, this piece had been offered to the Denver Art Museum (ibid). On 14 March 1973, Hollinshead and Fell were found guilty of both counts and in 1974 the district court opinion was affirmed by the United States Court of Appeal for the $9^{\text {th }}$ Circuit (United States vs. Hollinshead, 495 F.2d 1154, $9^{\text {th }}$ Cir, 1974; Hughes 1977: 149). Hollinshead was fined $\$ 5,000$, given a suspended sentence, and put on 5 years probation (Meyer 1973: 33). Fell also received a suspended sentence and 3 years, probation. Both Machaquilá were returned to Guatemala. 


\section{The Latin American antiquities trade post-1970}

There is little evidence that the 1970 UNESCO Convention had much of an impact on the illicit trade in Latin American cultural property. The Convention's focus on development of international partnerships for the return of a few very high profile antiquities does not seem to have address the on-the-ground needs of the region. Indeed a number of sources indicate that, in parts of Latin America, looting actually intensified after the 1970 Convention, particularly in the war-torn Petén region of Guatemala where rampant looting for Maya polychromes and other portable antiquities which the 1970s and 1980s left devastating scars on nearly every Maya site. Some of the highest profile looted antiquities from Latin America left post-1970 and many of them have not been recovered. The late 1980s and the early 1990s saw the looting of spectacular Moche tombs at Sipán, La Mina and other locations along Peru's North coast and only limited success with regard to the return of objects from those contexts. As previously stated, theft of colonial and republican sacred art increased greatly in the 1990s and 2000s and may not yet have hit its peak. What seems to be a reduction in looting incidents in traditional Latin American looting locations, e.g. Peru's North and South coasts and the Petén, likely had nothing to do with the UNESCO Convention, and more to do with some increased local police awareness and the fact that many, perhaps most archaeological sites in these areas have been exhausted. There is not much left to loot.

Thus in the 1970s and throughout the 1990s, it is likely that Latin American antiquities trafficking looked very similar to the trafficking networks seen in earlier periods. That said, we have very little evidence about the construction of these networks due to the systematic lack of convictions for antiquities trafficking at the 'demand' or 'market' end of the smuggling chain. An exception is the smuggling of some of the artefacts looted from Sipán. In one route, the objects were sent from Lima to London (via official corruption), repackaged and assigned a plausible false provenance, and were then sent to California where they were driven from the airport to the home of a potential buyer (Atwood 2004; Kirkpatrick 1992). In another, a large Sipán piece was taken from Peru to Panama where it was transferred to the diplomatic pouch of Francisco Humberto Iglesias, then the Panamanian Consul General to the United States. Iglesias knowingly smuggled the item into the United States where it was seized in an undercover FBI operation (FBI 1997; Wittman 2010).

At this stage, it is fair to characterize the current trade in illicit Latin American cultural property as largely opaque. It is no longer clear who is selling these items and no longer clear who is buying them. This is especially the case for sacred art and no case has yet publicly revealed the middle transit stages of the criminal networks that operate in this area now.

The case below is characteristic of the sort of major international Latin American cultural property smuggling cases that we see today. It features a particular factor that was, of course, not an issue before the late 1990s: the Internet as a collector/dealer tool for sharing new purchases and for detection of looted objects.

Network case study: Challapampa altarpiece (Peru)

Challapampa is a small indigenous village located in the district of Juli, in the Puno region of Peru. The village is home to the Capilla de San Pedro de Challapampa, a $16^{\text {th }}$ century Spanish colonial church. The church, which was declared to be National Cultural 
Patrimony in 1972 , contained a $16^{\text {th }}$ century mannerist-style altarpiece carved by Pedro de Vargas and painted by the acclaimed artist and Jesuit priest Alonso Bernardo Joan Democrito Bitti. It was constructed some time between 1575 and 1591 out of gilt cedar and maguay wood and decorated with polychrome paint. The altarpiece was originally created for the Picchu hacienda in Cuzco but was transferred to Challapampa in 1700. It is approximately 4 metres long, 3 metres high and weighs 450 kilograms (UNESCO 2006).

In January 2002, the altarpiece was disassembled and stored in a medical post near the church as part of a restoration project. It was stolen from this facility and the theft was immediately detected and reported. Initial speculation was that the thieves moved the piece across the border into Bolivia. In previous years, the church at Challapampa had been robbed of 14 paintings of archangels which some sources allege are now in Brazil (Frasier 2006).

In April 2003, the Embassy of Peru in the United States was notified via an anonymous phone call that the altarpiece had been trafficked to the United States and was being offered for sale on the Internet (Bush 2005). Peru reported this to the Department of Cultural Heritage of the US State Department and in May 2003, United States Immigration and Customs Enforcement (ICE) traced the piece to Ron Messick Fine Arts and Antiquities, a dealership operating out of Santa Fe, New Mexico (UNESCO 2006). On 6 May 2003, ICE took possession of the altarpiece under suspicion that its import violated the 1997 Memorandum of Understanding between the United States and Peru concerning the import of certain classes of cultural property (Arnold 2004; UNESCO 2006). When the piece was seized, the statue of the Virgin, which once stood in the central niche of the altarpiece was found to be missing. It has not been recovered.

It is unclear exactly how the object was moved from Peru to Santa Fe. A report prepared for Messick by Colorado-based appraiser Carol O'Brien English, appears to create a false ownership history for the altarpiece. It allegedly states that the piece entered the USA in 1961 as part of a collection from Spain and was sold to Messick by Arizona-based art dealer Paul S. Shephard in 2002 (Coleman 2005). Shephard denies this claim and English has stated that the story in her report was provided to her by Messick (Coleman 2005). Self-confessed former antiquities trafficker Michel van Rijn claimed that Messick displayed the altarpiece in his home before it was seized (Coleman 2005). At one point van Rijn offered to pay for the repatriation of the piece himself (Arnold 2004). Messick, via his lawyer Mark Donatelli, claimed that various stolen art registries were checked before the piece was acquired (Coleman 2005).

The ICE, Interpol, and the Attorney's Office in New York sought a criminal complaint against Ron Messick for his alleged hand in the trafficking and attempted illegal sale of the stolen altarpiece. A Federal Grand Jury was convened and the criminal prosecution of Messick was initiated by the US Attorney's Office in New York, however the prosecution was abated due to Messick's failing health (Coleman 2005). After it was seized in 2003, the altarpiece was moved to El Paso, Texas where it was positively identified by Rolando Paredes, Director of the National Institute of Culture in Puno, as being from Challapampa (Arnold 2004; Bush 2005). It was held in there storage until 2005 when it went on temporary display in Houston (Coleman 2005). On 20 January 2006 it was returned to Peru, and on 27 June 2006, it was restored to the Capilla de San Pedro de Challapampa. 


\section{The role of other regional forces and policy recommendation}

The looting and trafficking of Latin American cultural property cannot be viewed in isolation. It is only a very small component of some of the biggest issues that the region faces. It is not a separate problem and should not be treated as such. Regional instability from the narcotics and people trafficking, government failure and corruption, globalization and neoliberalism, developmental inequality and deforestation are what perpetuate on-the-ground threats to Latin American cultural property. To put it simply, if the goal is to protect Latin American cultural property on the ground, we must make people less poor, make people less insecure, and make Latin American governments less corrupt and more capable. In other words, broad international measures that are meant to focus on the source-end of the illicit antiquities market are likely to do very little as the underlying problems that cause cultural property threats will remain. Small-scale targeted capacity building may help in limited contexts (e.g. funding and training to secure a specific church), but not the greater issues.

Thus, policy focus must be at the market end of the trafficking chain. Demand causes supply and a reduction in demand for Latin American cultural property will result in a reduction of cultural property theft. Our focus should be discouraging criminality and punishing criminals rather than simple artefact recovery at all costs. Those caught engaging with the illegal antiquities market and those committing criminal acts should face the punitive damages for trafficking and receiving stolen gods afforded by local law and should not be allowed to simply surrender stolen artefacts to escape any charges. Furthermore, we should invest more time in developing better soft control techniques to discourage the market beyond ineffectual and obtuse codes of ethics by:

- introducing doubt into the market, e.g. by giving source country experts a platform on which to challenge the authenticity or legality of cultural property for sale,

- introducing more oversight into museum donation tax incentives,

- publicly lauding collectors and museums that do the right thing and publicly shaming those who do the wrong thing.

Some of these non-punitive market reduction measures have the added benefit of being inexpensive, important for developing countries. Many of them could effectively be deployed online. Some could be organized by the countries of origin and, in a sense, this could be a focus for funding ear-market for on-the-ground cultural property protection. There are many possibilities but few are being effectively utilized.

When it comes to the development of future policy, I urge a departure from the 1970 UNESCO model that focuses on country-to-country bilateral agreements. Countryspecific legislation, such as the UNESCO-based bilateral agreements between the governments of some Latin American countries and the United States (still the primary market for Latin American antiquities), is ineffectual. It is nearly impossible to absolutely prove that a particular artifact came from the ground of a particular country and did so after the bilateral agreement was signed. I argue that 'object-specific' legislation, which introduces import bans into market countries for whole classes of ancient object no matter their country of origin, such as the 1972 US law that prevents the import of all Central American sculptures, murals, and architectural elements (Public Law No. 92587, 19 U.S.C. $\$ 2091$ ), is much more effective at reducing the illicit trade in cultural 
property and is cheaper to enforce as specific country of origin need not be specifically determined in each case. As we see, the UN is moving to impose more country-specific bans on the movement of antiquities, I fear that we will not move away from the countryspecific model and that our international policy efforts will continue to have little effect.

Finally, more empirical academic research must be conducted on many of the unanswered questions involved in the theft, trafficking, and market for Latin American material. For example, there has been almost no research into sacred art theft and trafficking in any discipline: it is happening but we do not know how or why. Nonacademic reports may tie theft and destruction of many types of Latin American antiquities to encroachment and land clearings in protected areas, which itself is tied to complicated issues related to poverty, post-conflict, and other criminal trafficking activities. No academic work has focused on this. This is quite clearly due to a lack of sustained funding for this sort of research, both in Latin America and abroad. This lack of investment in primary research into the topic will likely ensure that most efforts to control cultural property trafficking are both ill-advised and ill-suited for the realities of the situations in which they will be applied.

\section{Acknowledgements}

The author has received funding for this research from the European Research Council under the European Union's Seventh Framework Programme (FP7/2007-2013)/erc Grant agreement no. 283873 GTICO, the Leverhulme Trust, and the Fulbright Program.

\section{References}

Alva, Walter. 2001. 'The Destruction, Looting and Traffic of the Archaeological Heritage of Peru'. In Trade in Illicit Antiquities: the Destruction of the World's Archaeological Heritage, edited by Neil Brodie, Jenny Doole, and Colin Refrew (Cambridge: McDonald Institute of Archaeology), pp. 89-96.

Arnold, John.2004. 'Seized Altar Languishesas Evidencein ElPaso'. In Albuquerque Journal, 1 August 2004. URL: < http://perma.cc/VX8K-T8UD > and URL: < http://web.archive. org/web/20150216195414/http://abqjournal.com/news/state/205578nm08-01-04.htm > [accessed 16 February 2015].

Atwood, Roger. 2004. Stealing History: Tomb Raiders, Smugglers, and the Looting of the Ancient World (New York: St. Martin's Press).

Bruhns, Karen O. and Kelker, Nancy L. 2009. Faking the Ancient Andes (Walnut Creek: Left Coast Press).

Coe, Michael. 1993. 'From Huaquero to Connoisseur: The Early Market in PreColumbian Art'. In Collecting the Pre-Columbian Past, edited by Elizabeth Hill Boone (Washington D.C.: Dumbarton Oaks), pp. 271-290.

Coggins, Clemency C. 1969. 'Illicit Traffic of Pre-Columbian Antiquities'. In Art Journal 29(1), pp. 94-114.

Coggins, Clemency C. 1976. 'New Legislation to Control the International Traffic in Antiquities'. In Archaeology, 29(1), pp. 14-15.

Coggins, Clemency C. 1998. 'United States Cultural Property Legislation: Observations of a Combatant'. In International Journal of Cultural Property, 7(1), pp. 52-68.

Coleman, Michael. 2005. 'Stolen Artifact Heads Home: Peru Altarpiece Recovered in City'. In Albuquerque Journal, 27 July 2006. URL: < http://perma.cc/E9FN-H3FD > 
and URL: < http://web.archive.org/web/20150216195612/http://www.abqjournal. com/news/washington/375137north_news0 7-27-05.htm > [accessed 16 February 2015].

FBI. 1997. 'Peruvian Back Flap, 1997'. URL: < http://perma.cc/SH7N-ZRWB > and URL: < http://web.archive.org/web/20150216195718/http://www.fbi.gov/philadelphia/ about-us/history/famous-cases/famous-cases-peruvian-back-flap-1997 > [accessed on 16 February 2014].

Fraser, Barbara J. 2006. 'Organized corruption: Stolen religious art is international trade'. In Catholic News Service, 10 March 2006. URL: < http://perma.cc/99GW-CJXD > and URL: < http://web.archive.org/web/20150216195908/http://www.catholicnews.com/ data/stories/cns/0601426.htm > [accessed 16 February 2015].

Gilgan, Elizabeth. 2001. 'Looting and the market for Maya objects: a Belizean perspective'. In Trade in Illicit Antiquities: the Destruction of the World's Archaeological Heritage, edited by Neil Brodie, Jenny Doole, and Colin Refrew (Cambridge: McDonald Institute of Archaeology).

Graham, Ian. 2010. The Road to Ruins (Abuquerque: University of New Mexico Press).

Gutchen, Mark A. 1983. 'The Destruction of Archaeological Resources in Belize, Central America. In Journal of Field Archaeology 10, pp. 217-227.

Hernández Sánchez. 2008. Edgar Herlindo. La máscara de Río Azul: un caso de tráfico ilícito del patrimonio cultural de Guatemala. Universidad de San Carlos De Guatemala [Licenciado Dissertation].

Hughes, William J. 1977. 'United States V. Hollinshead: A New Leap in Extraterritorial Appication of Criminal Laws'. In Hastings International and Comparative Law Review 1, pp. 149-173.

Just, Bryan R. 2007. 'Ninth-Century Stelae of Machaquilá and Seibal', FAMSI. URL:<http://web.archive.org/web/20150216200154/http://www.famsi.org/ reports/01050/01050Just01.pdf $>$ [accessed on 16 February 2015].

Kelker, Nancy L. and Bruhns, Karen O. 2009. Faking Ancient Mesoamerica (Walnut Creek: Left Coast Press).

Kirkpatrick, Sidney. 1992. Lords of Sipán: A True Story of Pre-Inca Tombs, Archaeology, and Crime (New York: William Morrow and Company).

La Porte, Juan Pedro, Héctor E. Mejía, Jorge E Chocón. 2009. 'Machaquila from a Regional Geographic Perspective. Paper given at the Symposium of Archaeological Investigations in Guatemala, 2004, FAMSI. URL: < http://perma.cc/K2SS-BCFG > and URL: < http://web.archive.org/web/20150216200326/http://www.famsi.org/ reports/03101/36laporte_mejia_chocon/36laporte_mejia_chocon.pdf $>$ [accessed on 16 February 2015].

Levine, Marc N. and Lucha Martínez de Luna. 2013. 'Museum Salvage: A Case Study of Mesoamerican Artifacts in Museum Collections and on the Antiquities Market'. In Journal of Field Archaeology, 38(3), pp. 264-276.

Luke, Christina and John S. Henderson. 2006. 'The Plunder of the Ulúa Valley, Honduras and a Market Analysis for its Antiquities'. In Archaeology, Cultural Heritage, and the Antiquities Trade, edited by Neil Brodie, Morag M. Kersel, Christina Luke, and Kathryn Walker Tubb (Gainsville, University Press of Florida), pp. 147-172.

Mackenzie, Simon and Tess Davis. 2014. 'Temple Looting in Cambodia: Anatomy of a Statue Trafficking Network'. In British Journal of Criminology, 54(5), pp. 722-740.

Meyer, Karl E. 1972. The Plundered Past (New York: Atheneum).

Paredes Maury, Sofia. 1996. Surviving in the Rainforest: The Realities of Looting in the 
Rural Villages of El Petén, Guatemala. [FAMSI Reports]. URL: < http://perma.cc/ B74R-4MJM > and URL: < http://web.archive.org/web/20150216200439/http://www. famsi.org/reports/95096/95096ParedesMaury01.pdf > [accessed 16 February 2015].

Pendergast, David M. 1991. 'And the Loot Goes On: Winning Some Battles, But Not the War'. In Journal of Field Archaeology 18, pp. 89-95.

Pendergast, David M. and Elizabeth Graham. 1981. 'Fighting a Looting Battle: Xunantunich, Belize'. In Archeology, 34(4), pp. 12-19.

Robertson, Merle Greene. 1972. 'Monument Thievery in Mesoamerica'. In American Antiquity, 37(2), pp. 147-155.

Sheets, Payson. 1973. 'The Pillage of Prehistory'. In American Antiquity, 38(3), pp. 317- 320.

Tello, Julio C. 1959. Paracas: Primera Parte. Publicación $8 b$ del Proyecto del Programa 1941-1942 de The Institute of Andean Research de New York (Lima: T. Scheuch).

UNESCO. 2006. 'Altarpiece of the Altar in Challapampa Returned to Peru'. In Regional Office for Culture in Latin America and the Caribbean News, 28 February 2006. URL: < http://perma.cc/8J5G-9RCN > [last accessed 17 September 2015].

Wittman, Robert. 2010. Priceless: How I went Undercover to Rescue the World's Stolen Treasures (New York: Crown).

Yates, Donna. 2006. South America on the block: the changing face of Pre-Columbian antiquities auctions in response to international law. [University of Cambridge: MPhil Thesis].

Yates, Donna. 2011. 'Archaeology and autonomies: the legal framework of heritage management in a new Bolivia. In International Journal of Cultural Property 18, pp. 291-307.

Yates, Donna. 2014a. 'Church theft, insecurity, and community justice: the reality of source-end regulation of the market for illicit Bolivian cultural objects'. In European Journal on Criminal Policy and Research, 20(4), pp. 445-457.

Yates, Donna. 2014b. 'Displacement, deforestation, and drugs: antiquities trafficking and the narcotics support economies of Guatemala'. In Cultural property crimes: an overview and analysis on contemporary perspectives and trends, edited by Joris Kila and Marc Balcells (Brill: Leiden). 